\title{
Amino acid profiles and anti-nutritional contents of traditionally consumed six wild vegetables
}

\author{
Hwiyang Narzary ${ }^{\mathrm{a}}$ and Sanjay Basumatary $\mathrm{b}^{\mathrm{b}^{*}}$
}

${ }^{a}$ Department of Biotechnology, Bodoland University, Kokrajhar-783370, Assam, India

${ }^{b}$ Department of Chemistry, Bodoland University, Kokrajhar-783370, Assam, India

\begin{tabular}{l}
\hline C H R O N I C L E \\
\hline Article history: \\
Received March 2, 2018 \\
Received in revised form \\
March 12, 2019 \\
Accepted April 12, 2019 \\
Available online \\
April 12, 2019 \\
\hline Keywords: \\
Wild vegetables \\
Amino acid profile \\
Essential amino acid \\
Anti-nutritional content
\end{tabular}

\begin{abstract}
A B S T R A C T
The present study was designed to evaluate the amino acid profiles and anti-nutritional contents of six wild vegetables viz. Cardamine hirsuta, Melothria perpusilla, Cryptolepis sinensis, Persicaria chinensis, Lippia javanica and Polygonum perfoliatum from Assam, India. The total amino acid detected was found the highest in P. chinensis as $25.92 \mathrm{mg} / \mathrm{g}$ dry weight (DW) followed by P. perfoliatum (19.68 mg/g DW) and M. perpusilla $(14.57 \mathrm{mg} / \mathrm{g} \mathrm{DW})$, and the lowest amino acid was observed in L. javanica $(0.62 \mathrm{mg} / \mathrm{g}$ DW). However, the highest nonessential amino acids (NEAA) were detected in P. perfoliatum $(3.89 \mathrm{mg} / \mathrm{g} \mathrm{DW})$. Among the NEAA, aspartic acid and glutamic acid were detected in all the six plant species which ranged from 0.01 to $0.33 \mathrm{mg} / \mathrm{g}$ DW and 0.02 to $0.75 \mathrm{mg} / \mathrm{g} \mathrm{DW}$, respectively. In this study, the highest concentration of essential amino acids (EAA) was detected in C. hirsuta $(1.72 \mathrm{mg} / \mathrm{g} \mathrm{DW})$ followed by M. perpusilla $(0.95 \mathrm{mg} / \mathrm{g} \mathrm{DW})$ and P. chinensis $(0.67 \mathrm{mg} / \mathrm{g} \mathrm{DW})$. Besides EAA and NEAA, some other amino acids such as phosphoserine, OH-proline, amino adipic acid, phosphoenolamine, and taurine are the most common which were detected. In the study, variable amounts of anti-nutritional contents were found and discussed herein.
\end{abstract}

C 2019 by the authors; licensee Growing Science, Canada.

\section{Introduction}

Wild vegetables are generally consumed by diverse indigenous and tribal inhabitants in different parts of the world since very long time. These vegetables have unique flavours and taste which are easily available and can be obtained throughout the year from uninhabited and forest areas. The green vegetables are considered as the potential sources of minerals, vitamins, amino acids and other bioactive compounds which are needed for proper maintenance of human health. ${ }^{1}$ These wild vegetables also possess various biological properties such as antimicrobial, antioxidant, anti-stress, anti-inflammatory, anti-allergic, hepatoprotective activity and many other. ${ }^{2-4}$ Cardamine hirsuta L. belonging to the family Brassicaceae is locally known as Singsab in Bodo in Assam of North-East India. It grows in stream, rivers and lakes as floating on the surface of water as well as in the muddy area. They have a pungent smell like mustard oil. Leaves are similar to the leaves of mustard oil. The plant is found available from the month of July to August. The leaves and the stems are eaten as vegetable. This plant has been reported for antioxidant and antimicrobial properties. ${ }^{4,5}$ Melothria perpusilla (Blume) Cogn. belongs to the family Cucurbitaceae. It is locally known as Timijora and is a climber and most commonly grow in ponds and lakes. The leaves are serrate hard, rigid margin, flowers are yellow, fruits show distinct margin diagonally at the middle through which it breaks into two equal

* Corresponding author. Tel.: +91-99543-36448; +91-70021-66299

E-mail address: waytosanjay12@gmail.com (S. Basumatary)

(C) 2019 by the authors; licensee Growing Science, Canada doi: $10.5267 /$ j.ccl.2019.004.002 
halves on ripening. It is available during the summer from March to August. The plants are eaten as a vegetable by the local people. The Bodo people have a traditional belief that this plant has medicinal values and it is used for curing joint pain, and jaundice. Singh et al. ${ }^{6}$ recently conducted an in vivo model study in albino rats with ethyl acetate extract of Melothria perpusilla and reported a significant reduction of intestinal glucose absorption. Similarly, aqueous extract of Melothria perpusilla was studied by Yengkhom et al. ${ }^{7}$ and they reported hepatoprotective property against $\mathrm{CCl}_{4}$ induced liver injury in the albino rats. This plant also possesses antioxidant and antimicrobial properties., ${ }^{4,5}$ Cryptolepis sinensis (Lour) Merr. is locally known as Parukia in Bodo and it belongs to the family Apocynaceae. It is a thin and hard stem climber, its leaves are opposite, flowers are very small and yellow in colour, fruits are long, bear in pair, and looks like a pencil. The plant is available from March to July every year. It bears latex and its tender leaves are traditionally consumed as vegetables by Bodo tribes especially for lactating mother to increase the milk production. Recently, the plant has been reported for antimicrobial and antioxidant properties. ${ }^{4,8}$ Persicaria chinensis (L.) H. Gross belonging to the family Polygonaceae is locally known as Mwisungka in Bodo. It is small herbs growing under the canopy of forest, leaves are simple, hairy with polygonous margin, inflorescence spikelet, and remains prostrate on the ground. It is available during the month of June to November. The young shoots are edible and sour in taste and have antioxidant property. ${ }^{5}$ Lippia javanica (Burm.f.) Spreng belongs to Verbenaceae family and is locally known as Ontaibajab in Bodo. It is a small woody shrub. The leaves have aromatic smell. The inflorescence spike, flowers are sessile, purple or pink in colour, and generally grow in sandy soil near a river or pond bank. The plant is generally found available from March to June. The leaves are eaten as vegetables by the Bodo people and is cooked with meat and fish also. It is used as herbal tea ${ }^{9}$, vegetables ${ }^{10}$, insect repellent ${ }^{11}$ and used in wounds, injuries, pain and skin infection $^{12}$. This plant has also been reported for antioxidant property ${ }^{8}$. Polygonum perfoliatum L. is locally known as Mwitasikla in Bodo. It belongs to Polygonaceae family and is an annual or perennial climber, and it grows on sandy soil. The petiole and stems are angular bearing recurved prickles. The fruits are metallic blue in colour, sub-globose, fleshy, and berry-like, 4 to $6 \mathrm{~mm}$ in diameter. The tender leaves are eaten as vegetables by the Bodo people, especially with fish or edible insects. These vegetables are available from the month of March to June. It has been reported that $P$. perfoliatum extracts possess cytotoxicity effects against colon carcinoma, human mammary carcinoma, hepatocellular carcinoma, prostate carcinoma, and erythro-leukaemia cells ${ }^{13}$. It has also been reported that $P$. perfoliatum have anti-inflammatory ${ }^{14}$, anti-bacteria $1^{15}$, and antioxidant properties ${ }^{8}$.

In the present study, we are reporting the amino acid compositions and anti-nutritional contents of these six non-conventional vegetables from Assam, India as there is no available report in the literatures about these study to the best of our knowledge.

\section{Materials and Methods}

\subsection{Materials}

A total of six wild vegetables viz. C. hirsuta, M. perpusilla, C. sinensis, P. chinensis, L. javanica and $P$. perfoliatum were collected during their available season from the village market of Kokrajhar district of Assam (India). The plants were identified at BSI, Shillong (Reference No. BSI/ERC/Tech/ Plant Iden./2015/77, Dated 05/05/2015; BSI/ERC/Tech./Plant Iden./2015/432, Dated 30/09/2015). After collection, the wild vegetables were washed properly with water, dried at $50^{\circ} \mathrm{C}$ in the oven for two days, and then the dry materials were grinded into fine powders which are stored in dry and cool place in a plastic container for analysis. Chemicals like $\mathrm{KMnO}_{4}$, dimethyl sulfoxide (DMSO), $\mathrm{HCl}$, $\mathrm{H}_{2} \mathrm{SO}_{4}$, sulfosalicylic acid, ethanol, methanol, acetic acid, $\mathrm{NH}_{4} \mathrm{OH} . \mathrm{FeCl}_{3} \cdot 6 \mathrm{H}_{2} \mathrm{O}$ and diethyl ether were obtained from Merck, Mumbai, India. Phytic acid, vanillin and catechin were obtained from Sigma Aldrich, Bangalore, India.

\subsection{Amino acid analysis by using reversed-phase high performance liquid chromatography (RP-HPLC)}

The powdered sample $(5 \mathrm{mg}$ ) was mixed with $5 \mathrm{~mL}$ of water and vortexed for $10 \mathrm{~min}$. It was followed by addition of methanol $(20 \mathrm{~mL})$ which was then incubated at $-20^{\circ} \mathrm{C}$ for overnight. The sample 
was again centrifuged and the supernatant was completely evaporated under nitrogen atmosphere at $60^{\circ} \mathrm{C}$. Thereafter, $250 \mu \mathrm{L}$ of PITC (Phenyl isothiocyanate) was added to the sample and it was vortexed for $1 \mathrm{~h}$ at $45^{\circ} \mathrm{C}$ followed by vacuum drying. It was again centrifuged by adding $1000 \mu \mathrm{L}$ of buffer $\mathrm{A}$ (10 mM sodium acetate at $\mathrm{pH} 6.4$ adjusted with $6 \%$ acetic acid) solution and the supernatant was filtered through syringe filter. Finally, $20 \mu \mathrm{L}$ of the prepared solution was loaded into RP-HPLC (Zorbax 300 SB, Agilent 1200 series, C18 column: $4.6 \times 250 \mathrm{~mm}, 254 \mathrm{~nm}$ ) and allowed to run for $82 \mathrm{~min}$ at the flow rate of $1 \mathrm{~mL} / \mathrm{min}$. The buffer B solution used was combination of acetonitrile and buffer $\mathrm{A}$ in the ratio of 60:40 (v/v). The standard sample was also allowed to run in the HPLC under same conditions.

\subsection{Determination of anti-nutritional contents}

The experiments for determination of anti-nutritional contents of powdered plant samples were performed as per reported procedures. ${ }^{16-20}$

\section{Results and Discussion}

\subsection{Amino acid composition}

In the present study, the amino acid profiles of the six wild vegetables were investigated using RPHPLC. The HPLC chromatograms of six wild vegetables are shown in Fig. 1-6. The amino acid profiles of the six wild vegetables in $\mathrm{mg} / \mathrm{g}$ of dry weight (DW) are presented in Table 1 . The total amino acid detected was found the highest in P. chinensis $(25.92 \mathrm{mg} / \mathrm{g})$ followed by $P$. perfoliatum $(19.68 \mathrm{mg} / \mathrm{g})$ and M. perpusilla $(14.57 \mathrm{mg} / \mathrm{g})$, and the lowest amino acid was observed in L. javanica $(0.62 \mathrm{mg} / \mathrm{g})$. However, the highest non-essential amino acids (NEAA) were detected in P. perfoliatum $(3.89 \mathrm{mg} / \mathrm{g} \mathrm{DW})$. Among the NEAA, aspartic acid and glutamic acid were detected in all the six plant species which varied from 0.01 to $0.33 \mathrm{mg} / \mathrm{g}$ and 0.02 to $0.75 \mathrm{mg} / \mathrm{g}$, respectively. Aspartic acid acts as a precursor for pyrimidine, purine, and asparagine and also it is involved in excretion of ammonia and detoxification. $^{21}$ The aspartic acid content of the present study is higher in comparison to the results reported in edible mushroom viz. Calvatia gigantea $(0.004 \mathrm{mg} / \mathrm{g} \mathrm{DW})^{22}$, but similar to that of domestic vegetable Raphanus sativus $(0.19 \mathrm{mg} / \mathrm{g} \mathrm{DW}),{ }^{23}$ and some wild vegetables such as Oxalis corniculata $(0.04 \mathrm{mg} / \mathrm{g})$, Chenopodium album $(0.05 \mathrm{mg} / \mathrm{g})$, and Chenopodium ambrosioides $(0.34 \mathrm{mg} / \mathrm{g}){ }^{24} \mathrm{He}$ et al. ${ }^{25}$ also reported comparable aspartic acid contents in two wild edible allium species viz. Allium chinense $(0.26 \mathrm{mg} / \mathrm{g})$ and Allium macrostemon $(0.14 \mathrm{mg} / \mathrm{g} \mathrm{FW})$. The glutamic acid content of current study (Table 1) is found similar to that of Allium chinense $(0.1 \mathrm{mg} / \mathrm{g})$ and Allium macrostemon $(0.64$ $\mathrm{mg} / \mathrm{g})$ reported by He et al. ${ }^{25}$ and also to that of Raphanus sativus $(0.66 \mathrm{mg} / \mathrm{g} \mathrm{DW})$ reported by Choi et al. ${ }^{23}$ However, Sun et al. ${ }^{26}$ reported higher amounts of glutamic acid contents in edible mushroom which ranged from $1.32 \mathrm{mg} / \mathrm{g}$ to $13.69 \mathrm{mg} / \mathrm{g}$ DW. Glutamic acid is a good neurotransmitter for spinal cord, brain and central nervous system, it helps in correction of physiological imbalances of the body and it also combat with the muscle hypertrophy after a protracted rest or chronic diseases such as AIDS and cancer ${ }^{21}$. In this study, serine was detected only in three species and these are M. perpusilla $(0.27 \mathrm{mg} / \mathrm{g})$, C. sinensis $(0.13 \mathrm{mg} / \mathrm{g})$ and $P$. chinensis $(0.05 \mathrm{mg} / \mathrm{g})$. These findings are comparable to the serine contents of some tea and tea products $(0.03$ to $1.85 \mathrm{mg} / \mathrm{g} \mathrm{DW})$ reported by Horanni et al. ${ }^{27}$ and also comparable to that of the leaves, fruits, stem and roots of Rubus amabilis which ranged from $0.02 \mathrm{mg} / \mathrm{g}$

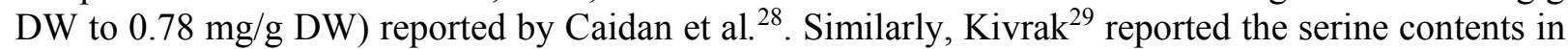
some unifloral honey of Turkey ranging from 0.002 to $1.17 \mathrm{mg} / \mathrm{g}$. In this study, low levels of the simplest amino acid glycine were detected only in C. sinensis $(0.18 \mathrm{mg} / \mathrm{g})$ and in L. javanica $(0.02$ $\mathrm{mg} / \mathrm{g} \mathrm{DW})$ which is found similar to that of radish $(0.06 \mathrm{mg} / \mathrm{g} \mathrm{DW})$ reported by Choi et al. ${ }^{23}$ and also to that of unifloral honeys of Turkey $(0.03 \mathrm{mg} / \mathrm{g}$ to $0.20 \mathrm{mg} / \mathrm{g})$ reported by Kivrak ${ }^{29}$. Similarly, the glycine contents in different varieties of buckwheat $(0.004$ to $0.1 \mathrm{mg} / \mathrm{g})$ reported by Peng et al. ${ }^{30}$ are comparable with the glycine contents of present study. However, Sun et al. ${ }^{26}$ reported higher amounts of glycine in some mushroom species ranging from $0.42 \mathrm{mg} / \mathrm{g}$ to $7.60 \mathrm{mg} / \mathrm{g}$ DW. However, asparagine was detected only in M. perpusilla $(0.22 \mathrm{mg} / \mathrm{g})$ and C. sinensis $(0.26 \mathrm{mg} / \mathrm{g})$ and it is found similar to that of some wild plants viz. Rumex dentatus $(0.22 \mathrm{mg} / \mathrm{g})$, Erigeron bonariensis $(0.31 \mathrm{mg} / \mathrm{g})$, and Chenopodium ambrosioides $(0.36 \mathrm{mg} / \mathrm{g}){ }^{24}$ The asparagine contents of present study are higher in 
comparison to the results of some sea grasses like Cymodocea serrulata $(0.03 \mathrm{mg} / \mathrm{g})$, Halophila ovalis $(0.04 \mathrm{mg} / \mathrm{g})$ and Halodule pinifolia $(0.03 \mathrm{mg} / \mathrm{g} \mathrm{DW})$ reported by Jeevitha et al. ${ }^{31}$, but it is lower compared to some mushroom species which ranged from 0.66 to $4.17 \mathrm{mg} / \mathrm{g}$. ${ }^{26}$ The alanine content of the present study is comparable to that of two wild species viz. Allium chinense $(0.29 \mathrm{mg} / \mathrm{g} \mathrm{DW})$ and Allium macrostemon $(0.21 \mathrm{mg} / \mathrm{g} \mathrm{DW})^{25}$, radish $(0.13 \mathrm{mg} / \mathrm{g} \mathrm{DW})^{23}$, Ageratum conyzoides $(0.23 \mathrm{mg} / \mathrm{g}$ FW) and Cenchrus ciliaris $(0.26 \mathrm{mg} / \mathrm{g} \mathrm{FW})^{24}$ and some unifloral honeys which ranged from 0.01 to $0.32 \mathrm{mg} / \mathrm{g} .{ }^{29} \mathrm{On}$ the other hand, the proline contents of current study are also found similar to that of some sea grasses such as Cymodocea serrulata $(0.06 \mathrm{mg} / \mathrm{g} \mathrm{DW})$ and Halophila ovalis $(1.1 \mathrm{mg} / \mathrm{g} \mathrm{DW})^{31}$ and also comparable to rice $(2.87 \mathrm{mg} / \mathrm{g} \mathrm{FW})^{32}$ and Rubus amabilis $(3.26 \mathrm{mg} / \mathrm{g} \mathrm{DW}){ }^{28}$ In this study, low level of arginine was detected only in $C$. sinensis $(0.01 \mathrm{mg} / \mathrm{g} \mathrm{DW})$ which is comparable with the results of Rubus amabilis $(0.04 \mathrm{mg} / \mathrm{g} \mathrm{DW})^{28}$, radish $(0.01 \mathrm{mg} / \mathrm{g} \mathrm{DW})^{23}$, and Cenchrus ciliaris $(0.02$ $\mathrm{mg} / \mathrm{g} \mathrm{DW}) .{ }^{24}$ However, higher amount of arginine has been reported in some mushroom species $(0.52$ $\mathrm{mg} / \mathrm{g}$ to $7.42 \mathrm{gm} / \mathrm{g}){ }^{26}$ Arginine is one of the important amino acids which has a significant role in hormone release, cell division, wound healing, immune function and ammonia removal. ${ }^{33}$

Table 1. Amino acid compositions of six wild vegetables in $\mathrm{mg} / \mathrm{g}$ of dry weight (DW)

\begin{tabular}{|c|c|c|c|c|c|c|}
\hline Amino Acids & C. hirsuta & M. perpusilla & C. sinensis & P. chinensis & L. javanica & P. perfoliatum \\
\hline \multicolumn{7}{|c|}{ Non-essential amino acids (NEAA) } \\
\hline Aspartic acid & 0.28 & 0.20 & 0.33 & 0.01 & 0.03 & 0.01 \\
\hline Glutamic acid & 0.53 & 0.75 & 0.23 & 0.03 & 0.02 & 0.05 \\
\hline Serine & -- & 0.27 & 0.13 & 0.05 & -- & -- \\
\hline Glycine & -- & -- & 0.18 & -- & 0.02 & -- \\
\hline Asparagine & -- & 0.22 & 0.26 & -- & -- & -- \\
\hline Alanine & -- & $-{ }_{-}^{0}$ & 0.22 & -- & -- & 0.05 \\
\hline Proline & -- & -- & 0.08 & -- & -- & 3.78 \\
\hline Arginine & -- & -- & 0.01 & -- & -- & - \\
\hline Total NEAA & 0.81 & 1.44 & 1.44 & 0.09 & 0.07 & 3.89 \\
\hline \multicolumn{7}{|c|}{ Essential amino acids (EAA) } \\
\hline Histidine & 0.06 & -- & 0.24 & 0.29 & 0.06 & -- \\
\hline Isoleucine & -- & -- & -- & -- & -- & 0.12 \\
\hline Methionine & 0.11 & 0.26 & -- & -- & -- & -- \\
\hline Threonine & -- & 0.57 & -- & -- & -- & -- \\
\hline Valine & -- & - & 0.06 & 0.38 & 0.10 & -- \\
\hline Tryptophan & -- & 0.12 & -- & -- & -- & -- \\
\hline Cysteine & 1.55 & -- & -- & -- & -- & -- \\
\hline Total EAA & 1.72 & 0.95 & 0.30 & 0.67 & 0.16 & 0.12 \\
\hline \multicolumn{7}{|c|}{ Other amino acids (OAA) } \\
\hline Phosphoserine & 0.99 & 0.47 & 0.77 & 0.26 & 0.39 & 0.30 \\
\hline Amino adipic acid & 7.92 & 9.79 & 3.00 & 0.29 & -- & 0.6 \\
\hline OH Proline & 0.15 & 0.08 & 0.08 & 0.03 & 0.003 & 0.02 \\
\hline Phosphoenolamine & 0.005 & 0.12 & 0.17 & 0.12 & -- & -- \\
\hline Taurine & 0.03 & 0.1 & 0.16 & 0.21 & -- & -- \\
\hline Carnosine & -- & -- & 5.79 & -- & -- & 14.75 \\
\hline 3-Methyl histidine & -- & -- & 0.01 & -- & - & -- \\
\hline 1-Methyl histidine & -- & 1.09 & 0.02 & -- & -- & -- \\
\hline Anserine & -- & -- & 0.19 & -- & -- & -- \\
\hline Cystathionine & 0.08 & 0.53 & 0.04 & -- & -- & -- \\
\hline bABA & -- & -- & -- & 24.25 & -- & -- \\
\hline Total OAA & 9.17 & 12.18 & 10.23 & 25.16 & 0.39 & 15.67 \\
\hline NEAA + EAA & 2.53 & 2.39 & 1.74 & 0.76 & 0.23 & 4.01 \\
\hline Total amino acids & 11.70 & 14.57 & 11.97 & 25.92 & 0.62 & 19.68 \\
\hline
\end{tabular}

In this study (Table 1), the highest concentration of essential amino acids (EAA) was found in $C$. hirsuta $(1.72 \mathrm{mg} / \mathrm{g})$ followed by M. perpusilla $(0.95 \mathrm{mg} / \mathrm{g})$ and P. chinensis $(0.67 \mathrm{mg} / \mathrm{g})$. Lower levels of histidine $(0.06$ to $0.29 \mathrm{mg} / \mathrm{g} \mathrm{DW})$ were detected in four plant species of current study which is comparable with the results of radish growing in light and dark condition $(0.12$ and $0.09 \mathrm{mg} / \mathrm{g} \mathrm{DW})$ reported by Choi et al. ${ }^{23}$ and two wild varieties of allium viz. Allium chinense $(0.20 \mathrm{mg} / \mathrm{g} \mathrm{DW})$ and Allium macrostemon $(0.14 \mathrm{mg} / \mathrm{g} \mathrm{DW})$ reported by He et al. ${ }^{25}$ and also comparable with free amino acid contents of various parts of Rubus amabilis $(0.13$ to $0.22 \mathrm{mg} / \mathrm{g} \mathrm{DW})$ reported by Caidan et al. ${ }^{28}$ Histidine plays an important role as the antioxidant in scavenging of free radicals and is also used for dealing with cardiovascular diseases. ${ }^{34}$ In present study, isoleucine was found only in P. perfoliatum $(0.12 \mathrm{mg} / \mathrm{g} \mathrm{DW})$ which is comparable to that of the free amino acids of Rubus amabilis (root, stem and fruits) that ranged from 0.01 to $0.42 \mathrm{mg} / \mathrm{g}$ DW reported by Caidan et al. ${ }^{28}$ and close to the results of Raphanus sativus growing in light and dark condition $(0.05 \mathrm{mg} / \mathrm{g}$ and $0.18 \mathrm{mg} / \mathrm{g} \mathrm{DW})$ reported by Choi et al. ${ }^{23}$ The methionine was observed only in C. hirsuta $(0.11 \mathrm{mg} / \mathrm{g})$ and M. perpusilla $(0.26 \mathrm{mg} / \mathrm{g})$ in current study which is higher in comparison to the results of radish growing in different conditions 
$(0.02 \mathrm{mg} / \mathrm{g} \text { and } 0.03 \mathrm{mg} / \mathrm{g} \mathrm{DW})^{23}$ and also to the results of Allium chinense $(0.03 \mathrm{mg} / \mathrm{g} \mathrm{DW})$ and Allium macrostemon $\left(0.08 \mathrm{mg} / \mathrm{g}\right.$ DW) reported by He et al. ${ }^{25}$ However, Shaheen et al. ${ }^{32}$ reported higher levels of methionine in rice $(2.06 \mathrm{mg} / \mathrm{g})$ and wheat flour $(2.20 \mathrm{mg} / \mathrm{g})$. Threonine was detected only one species viz. M. perpusilla $(0.57 \mathrm{mg} / \mathrm{g})$ and the result is found similar to that of Parthenium hysterophorus $(0.51$ $\mathrm{mg} / \mathrm{g})$ and found comparable to that of Rumex dentatus $(0.31 \mathrm{mg} / \mathrm{g})$ and Chenopodium ambrosioides $(0.44 \mathrm{mg} / \mathrm{g})$ in fresh weight basis reported by Kumar et al. ${ }^{24}$ Valine was detected in three species viz. C. sinensis $(0.06 \mathrm{mg} / \mathrm{g})$, P. chinensis $(0.38 \mathrm{mg} / \mathrm{g})$ and $L$. javanica $(0.10 \mathrm{mg} / \mathrm{g})$. Similarly, Horanni et al. ${ }^{27}$ reported valine contents in some tea and tea products which varied from 0.01 to $1.09 \mathrm{mg} / \mathrm{g} \mathrm{DW}$. Tryptophan was detected only in M. perpusilla $(0.12 \mathrm{mg} / \mathrm{g})$ which is within the range of some tea and tea products $(0.05$ to $0.67 \mathrm{mg} / \mathrm{g} \mathrm{DW})$ reported by Horanni et al. ${ }^{27}$ In this study, cysteine was observed only in $C$. hirsuta $(1.55 \mathrm{mg} / \mathrm{g} \mathrm{DW})$ which is similar to the results of rice $(1.40 \mathrm{mg} / \mathrm{g} \mathrm{DW})$ and wheat flour $(2.18 \mathrm{mg} / \mathrm{g} \mathrm{DW})$ reported by Shaheen et al. ${ }^{32}$ and also to different parts of Rubus amabilis (1.67 to $2.11 \mathrm{mg} / \mathrm{g} \mathrm{DW}) .^{28}$

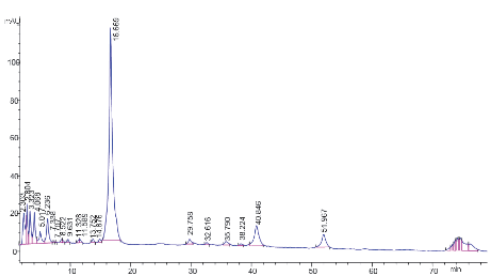

Fig. 1. HPLC chromatogram of C. hirsuta

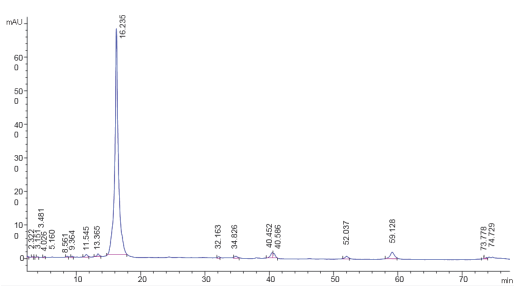

Fig. 4. HPLC chromatogram of $P$. chinensis

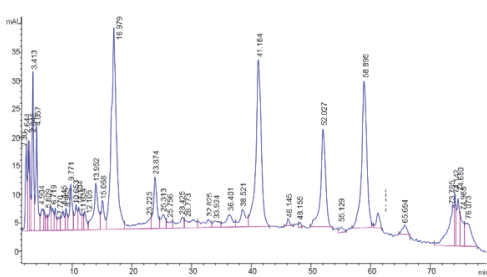

Fig. 2. HPLC chromatogram of M. perpusilla

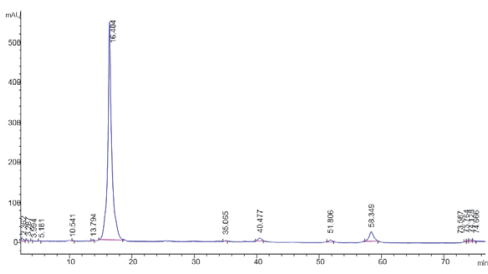

Fig. 5. HPLC chromatogram of L. javanica

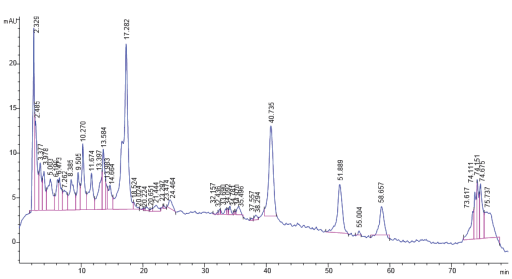

Fig. 3. HPLC chromatogram of C. sinensis

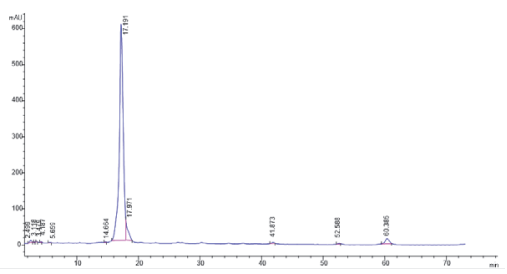

Fig. 6. HPLC chromatogram of $P$. perfoliatum

Besides EAA and NEAA, some other amino acids (non-protein amino acids) were also detected in the present study which is shown in Table 1. In this study, phosphoserine and OH-proline were detected in all the selected plant species. Phosphoserine was found to be the highest in C. hirsuta $(0.99 \mathrm{mg} / \mathrm{g})$ followed by $C$. sinensis $(0.77 \mathrm{mg} / \mathrm{g})$, and the lowest amount of phosphoserine was detected in $P$. chinensis $(0.26 \mathrm{mg} / \mathrm{g})$. In a study, Choi et al. ${ }^{23}$ reported low levels of phosphoserine in different varieties of potato that ranged from $0.14 \mathrm{mg} / \mathrm{g}$ to $0.23 \mathrm{mg} / \mathrm{g}$. The amino adipic acid was detected in all the plant samples which varied from 0.29 to $9.79 \mathrm{mg} / \mathrm{g}$ DW except L. javanica (Table 1). The OHproline was found in the range from 0.003 to $0.15 \mathrm{mg} / \mathrm{g}$ DW. Phosphoenolamine $(0.005$ to $0.17 \mathrm{mg} / \mathrm{g}$ DW) and taurine ( 0.03 to $0.21 \mathrm{mg} / \mathrm{g} \mathrm{DW})$ were detected in four plant species. The carnosine was detected only in two samples viz. C. sinensis $(5.79 \mathrm{mg} / \mathrm{g})$ and $P$. perfoliatum $(14.75 \mathrm{mg} / \mathrm{g})$ and it is found comparable with results of different varieties of potato (13.6 to $32.0 \mathrm{mg} / \mathrm{g} \mathrm{DW}) .{ }^{23} 3-\mathrm{Methyl}$ histidine $(0.01 \mathrm{mg} / \mathrm{g})$ and anserine $(0.19 \mathrm{mg} / \mathrm{g})$ were detected only in $C$. sinensis. $\beta$-amino butyric acid (bABA) was detected only in $P$. chinensis as $24.25 \mathrm{mg} / \mathrm{g}$ DW (Table 1). $\beta$-amino butyric acid helps in prevention of obesity by increasing the production of gut hormone (leptin). ${ }^{35}$ In this study, cystathionine was found in C. hirsuta $(0.08 \mathrm{mg} / \mathrm{g})$, M. perpusilla $(0.53 \mathrm{mg} / \mathrm{g})$ and C. sinensis $(0.04 \mathrm{mg} / \mathrm{g})$ which is similar to the results of two wild varieties of allium viz. Allium chinense $(0.07 \mathrm{mg} / \mathrm{g} \mathrm{DW})$ and Allium macrostemon $(0.13 \mathrm{mg} / \mathrm{g} \mathrm{DW})$ reported by He et al. ${ }^{25}$

\subsection{Anti-nutritional contents}

The anti-nutritional contents of the six wild vegetables are presented in the Table 2. The highest oxalate content was found in C. sinensis $(15.04 \pm 0.18 \mathrm{mg} / \mathrm{g}$ DW) followed by C. hirsuta $(13.65 \pm 0.34$ 
$\mathrm{mg} / \mathrm{g} \mathrm{DW})$ and the lowest oxalate content was detected in $M$. perpusilla $(6.315 \pm 0.92 \mathrm{mg} / \mathrm{g} \mathrm{DW})$. These results are within the range of oxalate contents of some edible fruits $(1.1 \pm 0.22 \mathrm{mg} / \mathrm{g}$ DW in Syzygium cumini to $25.08 \pm 6.11 \mathrm{mg} / \mathrm{g}$ DW in Aegle marmelos) reported by Rout et al. ${ }^{36}$ However, Adeniyi et al. ${ }^{37}$ reported lower oxalate contents in some food plants found in Nigeria which was in the range from $0.20 \mathrm{mg} / \mathrm{g}$ to $0.91 \mathrm{mg} / \mathrm{g}$. Similarly, Anhwange et al. ${ }^{38}$ reported the oxalate contents in some fruits which varied from $0.01 \mathrm{mg} / 100 \mathrm{~g}$ to $0.53 \mathrm{mg} / 100 \mathrm{~g}$ which is much lower in comparison to the present study. Choudhury et al. ${ }^{39}$ reported lower oxalate contents in some wild plants such as Enhydra fluctuans $(0.7 \mathrm{mg} / \mathrm{g})$, Eryngium foetidum $(0.6 \mathrm{mg} / \mathrm{g})$, Persicaria chinensis $(0.3 \mathrm{mg} / \mathrm{g})$, and Stellaria media $(0.3 \mathrm{mg} / \mathrm{g})$. High amounts of oxalic acid in the food can bind with elements to form oxalates in the gastrointestinal tract which is responsible for the formation of calcium oxalate stones in the kidney. ${ }^{40}$ Tannins are phenolic compounds which are soluble in water and polar organic solvents and tannins can combine with protein and form tannin-protein complexes which inhibit the digestive enzymes and reduce the digestibility of protein. ${ }^{41}$ In this study (Table 2), tannin was found varying from $1.02 \pm 0.01 \mathrm{mg} / \mathrm{g}$ in C. hirsuta to $8.80 \pm 0.05 \mathrm{mg} / \mathrm{g}$ in C. sinensis. Similarly, Choudhury et al. ${ }^{39}$ also reported tannin contents in some wild plants which ranged from $3.7 \mathrm{mg} / \mathrm{g} \mathrm{DW}$ (Stellaria media) to $8.90 \mathrm{mg} / \mathrm{g}$ DW (Oxalis corniculata). However, Agbaire ${ }^{42}$ reported the lower amounts of tannin in leafy vegetables of Nigeria which ranged from $0.04 \pm 0.01 \mu \mathrm{g} / \mathrm{g}$ to $0.26 \pm 0.03 \mu \mathrm{g} / \mathrm{g}$. In this study, the concentration of phytate was observed to be ranging from $4.60 \pm 0.17 \mathrm{mg} / \mathrm{g} \mathrm{DW}$ in $P$. perfoliatum to $9.22 \pm 0.10 \mathrm{mg} / \mathrm{g} \mathrm{DW}$ in $C$. hirsuta which is found similar with the phytate contents in the wild fruits $(3.62 \pm 0.30 \mathrm{mg} / \mathrm{g}$ DW in Mimusops elengi to $9.51 \pm 0.33 \mathrm{mg} / \mathrm{g}$ DW in Toddalia asiatica) reported by Rout and Basak. ${ }^{36}$ It has been reported that phytic acid can bind with several important minerals like iron, zinc, calcium, phosphorus, etc. and they form insoluble phytate complexes which are not being able to be absorbed by the body and thereby reduce their bioavailability and digestion in humans. ${ }^{43}$ The saponin content of the present study ranged from $3.23 \pm 0.30 \mathrm{mg} / \mathrm{g}$ in L. javanica to $14.13 \pm 0.92 \mathrm{mg} / \mathrm{g}$ in P. perfoliatum which is followed by $C$. hirsuta $(13.90 \pm 0.91 \mathrm{mg} / \mathrm{g})$. Similarly, Choudhury et al. ${ }^{39}$ also reported saponin contents in some leafy vegetables which were found ranging from $2.60 \mathrm{mg} / \mathrm{g} \mathrm{DW}$ to $7.40 \mathrm{mg} / \mathrm{g}$ DW. Saponins play some beneficial roles in limited doses because they have the properties of modifying the permeability of small intestine, and thus help in absorption of specific drugs, and they also act as neutral steroids and reduce serum cholesterol by secretion of bile acid. ${ }^{44}$ Alkaloids were found to be ranging from $0.31 \pm 0.01 \mathrm{mg} / \mathrm{g} \mathrm{DW}$ (C. sinensis) to $3.22 \pm 0.01 \mathrm{mg} / \mathrm{g} \mathrm{DW}$ (M. perpusilla) in the present study. Sotelo et al. ${ }^{45}$ reported alkaloid contents in some edible flowers such as Erythrina americana $(0.37 \pm 0.01 \mathrm{mg} / \mathrm{g} \mathrm{DW})$ and Erythrina caribaea $(0.24 \pm 0.03 \mathrm{mg} / \mathrm{g} \mathrm{DW})$. Similarly, Adeniyi et al. ${ }^{37}$ also reported low amounts of alkaloid contents in some food plants of Nigeria ranging from 0.11 $\mathrm{mg} / \mathrm{g} \mathrm{FW}$ to $0.29 \mathrm{mg} / \mathrm{g} \mathrm{FW}$. Consumption of excess amount of alkaloids may cause gastro-intestinal and neurological disorders. ${ }^{46}$

Table 2. Anti-nutritional contents of wild edible plants in $\mathrm{mg} / \mathrm{g}$ dry weight

\begin{tabular}{llllll}
\hline Plants & Oxalate & Saponin & Tannin & Phytate & Alkaloids \\
\hline C. hirsuta & $13.65 \pm 0.34^{a}$ & $13.90 \pm 0.91^{a}$ & $1.02 \pm 0.01^{a}$ & $9.22 \pm 0.10^{a}$ & $1.34 \pm 0.00^{a}$ \\
M. perpusilla & $6.315 \pm 0.92^{b}$ & $14.40 \pm 0.30^{b}$ & $4.47 \pm 0.01^{b}$ & $7.68 \pm 0.01^{b}$ & $3.22 \pm 0.01^{b}$ \\
C. sinensis & $15.04 \pm 0.18^{c}$ & $5.56 \pm 1.17^{c}$ & $8.80 \pm 0.05^{c}$ & $5.41 \pm 0.19^{c}$ & $0.31 \pm 0.01^{c}$ \\
$P$. chinensis & $11.68 \pm 0.24^{d}$ & $5.30 \pm 0.62^{c}$ & $4.10 \pm 0.06^{b}$ & $7.50 \pm 0.07^{b}$ & $0.69 \pm 0.01^{c}$ \\
L. javanica & $10.39 \pm 0.29^{e}$ & $3.23 \pm 0.30^{d}$ & $2.44 \pm 0.07^{d}$ & $7.20 \pm 0.08^{b}$ & $1.28 \pm 0.01^{a}$ \\
$P$. perfoliatum & $9.49 \pm 0.47^{f}$ & $14.13 \pm 0.92^{b}$ & $1.30 \pm 0.13^{a}$ & $4.60 \pm 0.17^{d}$ & $0.89 \pm 0.01^{c}$ \\
\hline
\end{tabular}

Results are presented as mean of three replicates \pm standard deviation and the values with different letters in a column are different significantly from each other at $p<0.05$ (executed by the one-way ANOVA $t$-test using MA 01060, OriginLab Corporation, USA)

\section{Conclusion}

In this study, the total amino acid detected was observed the highest in P. chinensis $(25.92 \mathrm{mg} / \mathrm{g}$ DW) and the lowest was found in L. javanica $(0.62 \mathrm{mg} / \mathrm{g} \mathrm{DW})$. A total of eight NEAA were detected in $C$. sinensis and $P$. perfoliatum $(3.89 \mathrm{mg} / \mathrm{g}$ DW) contained the highest NEAA. However, the highest EAA was detected in C. hirsuta $(1.72 \mathrm{mg} / \mathrm{g}$ DW) followed by $M$. perpusilla $(0.95 \mathrm{mg} / \mathrm{g} \mathrm{DW})$ and $P$. chinensis $(0.67 \mathrm{mg} / \mathrm{g}$ DW). Aspartic acid and glutamic acid were found as the most abundant NEAA 
in all the selected plant species, whereas histidine was found as the most abundant EAA. Among the other amino acids detected, phosphoserine and $\mathrm{OH}$-proline were detected in all the wild vegetables studied. Amino adipic acid was also detected in all the plant species except in L. javanica. The wild vegetable viz. $C$. sinensis exhibited the highest oxalate $(15.04 \pm 0.18 \mathrm{mg} / \mathrm{g})$ and tannin $(8.80 \pm 0.05$ $\mathrm{mg} / \mathrm{g})$ contents. In this study, low levels of alkaloids $(0.31 \pm 0.01$ to $3.22 \pm 0.01 \mathrm{mg} / \mathrm{g} \mathrm{DW})$ were observed. Amino acid profiles and anti-nutritional contents of these vegetables were reported herein for the first time. All these studied vegetables have potentials as valuable food for human nutrition.

\section{Acknowledgment}

The authors acknowledge CDFD, Hyderabad for amino acid analysis and the Head, Department of Food Engineering and Technology, Central Institute of Technology, Kokrajhar, Assam (India) for providing necessary facilities for the study of anti-nutritional contents. HN is thankful to the University Grants Commission, New Delhi for Rajiv Gandhi National Fellowship.

\section{References}

1. $\quad$ Kraft, T.F.B., Dey, M., Rogers, R.B., Ribnicky, D.M., Gipp, D.M., Cefalu, W.T., Raskin, I., Lila, M.A. (2008) Phytochemical composition and metabolic performance enhancing activity of dietary berries traditionally used by Native North Americans. J. Agric. Food Chem. 56, 654-660.

2. Mishra, A., Sharma, A.K., Kumar, S., Saxena, A.K., Pandey, A.K. (2013) Bauhinia variegata leaf extracts exhibit considerable antibacterial, antioxidant, and anticancer activities. BioMed Res. Int. 915436.

3. Arun, L.B., Arunachalam, A.M., Arunachalam, K.D., Annamalai, S.K., Kalaivani, A.K. (2014) In vivo anti-ulcer, anti-stress, anti-allergic, and functional properties of Gymnemic Acid Isolated from Gymnema sylvestre $\mathrm{R} \mathrm{Br}$. BMC Complement. Altern. Med. 14, 70.

4. Narzary H., Islary A., Basumatary S. (2018) Study of antimicrobial properties of six wild vegetables of medicinal value consumed by the Bodos of Assam, India. Medicinal Plants 10 (4) 363-368.

5. Basumatary, S., Narzary, H. (2017) Nutritional value, phytochemicals and antioxidant property of six wild edible plants consumed by the Bodos of North-East India. Mediterranean J. Nutr. Metabol. 10(3) 259-271.

6. Singh, S.V.J., Usham, D.M., Akham, S.D., Sanjenbam, R.D. (2017) Effect of ethyl acetate extract of Melothria perpusilla on intestinal absorption of glucose in albino rats. Int. J. Basic Clin. Pharmacol. 6(3) 543-546.

7. Yengkhom, N.S., Gunindro, N., Kholi, S.M., Moirangthem, R.S., Rajkumari, B.D. (2017) Hepatoprotective effect of aqueous extract of Melothria perpusilla against carbon tetrachloride induced liver injury in albino rats. Int. J. Res. Med. Sci. 5(3) 806-810.

8. Narzary, H., Islary, A., Basumatary, S. (2016) Phytochemicals and antioxidant properties of eleven wild edible plants from Assam, India. Mediterranean J. Nutr. Metabol. 9(3) 191-201.

9. Bhebhe, M., Chipurura, B., Muchuweti, M. (2015) Determination and comparison of phenolic compound content and antioxidant activity of selected local Zimbabwean herbal teas with exotic Aspalathus linearis. South Afr. J. Bot. 100(1) 213-218.

10. Narzary, H., Swargiary, A., Basumatary, S. (2015) Proximate and vitamin C analysis of wild edible plants consumed by Bodos of Assam, India. J. Mol. Pathophysiol. 4(4) 128-133.

11. Narayana, V.L., Narasimharao, G.M. (2015) Plants used in ethnoveterinary medicine by tribal of Visakhapatnam and Vizianagarm districts, Andhra Pradesh, India. Int. J. Pure Appl. Biosci. 3(2) 432-439.

12. Afolayan, A.J., Grierson, D.S., Mbeng, W.O. (2014) Ethno botanical survey of medicinal plants used in the management of skin disorders among the Xhosa communities of the Amathole District, Eastern Cape, South Africa. J. Ethnopharmacol. 153(1) 220-232.

13. Wang, K.W., Zhu, J.R., Shen, L.Q. (2013) A new lignin with antitumor activity from Polygonum perfoliatum L. Nat. Prod. Res. 27, 568-573.

14. Huang, H.F., Zhang, C.C., Yuan, D., Zhou, Z.Y. (2008) Anti-inflammatory and antibacterial effects of Polygonum perfoliatum L. Anhui Med. Pharm. J. 12, 595-596.

15. Fu, Y.X., He, X.R., Li, J.C., Liu, X.X. (2008) Study of chemical constitution and antibacterial effect of herb Polygonum perfoliatum L. Progress in Veterinary Medicine 29, 45-49.

16. Day, R.A., Underwood, A.L. (1986) Quantitative analysis. $5^{\text {th }}$ edn. Prentice-Hall publication. 701.

17. Price, M.L., Van-Scoyoc, S., Butler, L.G. (1978) A critical evaluation of vanillin reaction as an assay for tannin in sorghum. J. Agric. Food Chem. 26, 1214-1218.

18. Vaintraub, I.A., Lapteva, N.A. (1988) Colorimetric determination of phytate in un-purified extracts of seed and the products of their processing. Anal. Biochem. 17, 227-230.

19. Obadoni, B.O., Ochuko, P.O. (2001) Phytochemical studies and comparative efficacy of crude extracts of some homeostatic plants in Edo and delta states of Nigeria. Global J. Pure Appl. Sci. 8, 203-208. 
20. Griffiths, D.O. (2000) The inhibition of enzymes by extract of field beans (Vicia faba). J. Sci. Food Agric. 30, 458462.

21. Wu, G. (2009) Amino acids: Metabolism, functions, and nutrition. Amino Acids 37, 1-17.

22. Kivrak, I. Kivrak, S. Harmandar, M. (2014) Free amino acid profiling in the giant puffball mushroom (Calvatia gigantea) using UPLC-MS/MS. Food Chem. 158, 88-92.

23. Choi, H.S., Jang, S.J., Park, H.J., Yun, Y.B., Kuk, Y.I. (2015) Regeneration, nutritional values, and antioxidants in excised adventitious shoot of radish affected by dark treatment. J. Food Nutr. Res. 3, 365-370.

24. Kumar, V., Sharma, A., Thukral, A.K., Bhardwaj, R. (2015) Amino acid profiling of the leaves of plants in the vicinity of river Beas, India. J. Chem. Pharm. Res. 7(11) 504-510.

25. He, Q., Huang, S., Wu, Y., Zhang, W., Wang, F., Cao, J., Sheng, Q., Liang, Z., Liu, L., Ou, W.B. (2018) Comparative study on the composition of free amino acids and derivatives in the two botanical origins of an edible Chinese herb "Xiebai", i.e., Allium chinense G. Don and Allium macrostemon Bunge species. Food Res. Int. 106, 446-457.

26. Sun, L., Liu, Q., Bao, C., Fan, J. (2017) Comparison of free total amino acid compositions and their functional classifications in 13 wild edible mushrooms. Molecules 22, 350.

27. Horanni, R., Engelhardt, U.H. (2013) Determination of amino acids in white, green, black, oolong, pu-erh teas and tea products. J. Food. Compos. Anal. 31, 94-100.

28. Caidan, R., Cairang, L., Liu, B., Suo, Y. (2014) Amino acid, fatty acid, and mineral compositions of fruit, stem, leaf and root of Rubus amabilis from the Qinghai-Tibetan Plateau. J. Food Compos. Anal. 33, 26-31.

29. Kivrak, I. (2015) Free amino acid profiles of 17 Turkish unifloral honeys. J. Liq. Chromatogr. Relat. Technol. 38, 855-862.

30. Peng, L.X., Zou, L., Tan, M.L., Deng, Y.Y., Yan, Y., Yan, Z.Y., Zhao, G. (2017) Free amino acids, fatty acids, and phenolic compounds in tartary buckwheat of different hull colour. Czech J. Food Sci. 35, 214-222.

31. Jeevitha, M., Athiperumalsami, T., Kumar, V. (2013) Dietary fibre, mineral, vitamin, amino acid and fatty acid content of sea grasses from Tuticorin Bay, Southeast coast of India. Phytochem. 90, 135-146.

32. Shaheen, N., Islam, S., Munmun, S., Zaman, M.M., Longvah, T. (2016) Amino acid profiles and digestible indispensable amino acid scores of proteins from the prioritized key foods in Bangladesh. Food Chem. 213, 83-89.

33. Mohanty, B., Mahanty, A., Ganguly, S., Sankar, T.V., Chakraborty, K., Rangasamy, A., Paul, B., Sarma, D., Mathew, S., Asha, K.K., Behera, B., Aftabuddin, M., Debnath, D., Vijayagopal, P., Sridhar, N., Akhtar, M.S., Sahi, N., Mitra, T., Banerjee, S., Paria, P., Das, D., Vijayan, K.K., Laxmanan, P.T., Sharma, A.P. (2014) Amino acid compositions of 27 food fishes and their importance in clinical nutrition. J. Amino Acids 1-7.

34. Michael, A.W., Hugh, N.T. (1998) Antioxidant characteristics of L-histidine. J. Nutr. Biochem. 9, 308-315.

35. Begriche, K., Massart, J., Fromenty, B. (2010) Effects of $\beta$-aminoisobutyric acid on leptin production and lipid homeostasis: Mechanisms and possible relevance for the prevention of obesity. Fundam. Clin. Pharmacol. 24, 269282.

36. Rout, P., Basak, U.C. (2014) Evaluation of anti-nutritional factors in sixteen wild edible fruits of Odisha, India. Curr. Sci. Int. 13, 34-42.

37. Adeniyi, S.A., Orjiekwe C.L., Ehiagbonare, J.E. (2009) Determination of alkaloids and oxalates in some selected food samples in Nigeria. Afr. J. Biotechnol. 8(1) 110-112.

38. Anhwange, B.A., Tyohemba, R.L., Tukura B.W., Ogah, P. (2015) Screening of some indigenous wild fruits for antinutritional factors. J. Sci. Res. Report 5(3) 220-227.

39. Choudhury, B.H., Baruah, A.M., Sarmah, T.C., Baishya, S. (2017) Nutritional and anti-nutritional composition of twenty five indigenous leafy vegetables of Jorhat district of Assam state, India. Asian J. Chem. 29(1) 65-68.

40. Bele, A.A., Jadhav, V.M., Kadam, V.J. (2010) Potential of Tannins: A Review. Asian Journal of Plant Sciences 9(4) 209-214.

41. Abara, A.E. (2003) Tannin content of Dioscorea bulbufera. J. Chem. Soc. Nigeria. 28, 55-56.

42. Agbaire, P.O. (2012) Levels of anti-nutritional factors in some common leafy edible vegetables of southern Nigeria. Afr. J. Food Sci. Technol. 3(4) 99-101.

43. Thompson, L. U. (1993) Potential health benefits and problems associated with anti-nutrients in foods. Food Res. Int. 26: 131-149.

44. Dini, I., Schettino, O., Simioli, T., Dini, A. (2001) Studies on the constituents of Chenopodium quinoa seeds: Isolation and characterization of new triterpene saponins. J. Agric. Food Chem. 49(2) 741-746.

45. Sotelo, A., López-García, S., Basurto-Peña, F. (2007) Content of nutrient and anti-nutrient in edible flowers of wild plants in Mexico. Plant Foods Hum. Nutr. 62, 133-138.

46. Islary A., Sarmah J., Basumatary S. (2018) Antibacterial property and anti-nutritional contents of five wild fruits of Assam, India. J. App. Pharm. Sci. 8(12) 170-175.

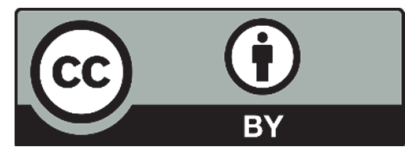

(C) 2019 by the authors; licensee Growing Science, Canada. This is an open access article distributed under the terms and conditions of the Creative Commons Attribution (CC-BY) license (http://creativecommons.org/licenses/by/4.0/). 